\title{
Canadian Association of African Studies
}

THE fifth Annual Conference of the Canadian Association of African Studies will be held at the main campus of York University, Toronto, Ontario, from 19 to 22 February 1975. The Conference theme is : 'African Social and Political Thought', a title which encompasses such topics as traditional cosmologies, woman's lot, social reform movements, élite formation, socio-linguistics, law, social policies concerned with health, education and 'development', etc.

Inquiries should be addressed to: Dr. Paul Lumsden, Chief Organizer, C.A.A.S. Conference, Room S814, Ross Bldg., York University, 4700 Keele St., Toronto, Ont. Canada.

\section{Field Museum of Natural History, Chicago}

A traveling exhibition of contemporary African art organized by the Chicago Field Museum of Natural History, is to visit major cities in the U.S.A. and Canada in 1975 and 1976. The exhibits, some from the Museum's own collection, others on loan from other museums or private collections, include aluminium panels by Asiru Olatunde from Oshogbo, a variety of West African textile patterns as seen in the work of Kadiato Kamara from Sierra Leone, pottery by Lai Kwali from Nigeria, print-making by Bruce Onobrakpeya from Oshogbo, sculpture by Thomas Mukarebgwa from Rhodesia, paintings by Skunder Borghossian from Ethiopia, tapestries from the Egyptian workshop founded by Ramses Wissa Wassaf and examples of calabash carvings by Peter Nzuki from Nairobi. Accompanying the exhibition will be musical presentations by Akin Euba of the University of Ife, and poetry by the South African Dennis Brutus.

\section{University of Aberdeen: Colloquium on Senegambia}

A Collopuium on Senegambia was held at the University of Aberdeen, arranged by the African Studies Group of the University, between 3 and ; April 1974. There were about thirty participants, including H.E. Seydina Sy, Senegalese Ambassador to Brussels, H.E. B. Senega-Janneh, the Gambian High Commissioner in the U.K., and Professor Y. Person of the University of Paris. The Colloquium opened with a public lecture by Professor Person on 'Senegambia in History'. This was followed by three sessions. At the first, on 'Unity and diversity in the history of Senegambia', papers were presented by Professor J. D. Hargreaves (Aberdeen), M. A. Bathily (Centre of West African Studies, Birmingham), and Mr. A. Mboge (Aberdeen). The second session concerned 'Some present realities', papers being presented by Mr. Kaye Whiteman (Commission of the European Communities, Brussels) and Dr. A. Adams (Aberdeen). The last session dealt with 'Prospects for co-operation', papers being presented by H.E. Seydina Sy, Miss Carew Treffgarne (Institute of Education, London), and Dr. Arnold Hughes (C.W.A.S., Birmingham). Interesting and lively discussions followed the papers, and a report on these will be included with the papers themselves in a record of the proceedings of the Colloquium. This is now available from the Aberdeen University African Studies Group, Taylor Building, King's College, Aberdeen.

\section{'Culture et développement' (Université Catholique de Lowain) vol. vi, no. 2}

\section{Articles}

Toyomasa Fusé. Japan's Economic Cooperation in Southeast Asia : Its Scope, Prospects and Assessment.

F. Rodegem. La fonction hyperphatique du langage. 